Original Research Paper

\title{
Pemanfaatan Kulit Pisang Menjadi Produk Kopi Bubuk (KoKuPis)
}

\author{
Dewi Putri Lestari ${ }^{1}$, Muhamad Rachmat Wijaya ${ }^{2 *}$, Feri Febriyanto Rachman ${ }^{2}$, Alpian Hadi Wisastra ${ }^{3}$, \\ Anharudin ${ }^{2}$ \\ ${ }^{\text {I} P r o g r a m ~ S t u d i ~ B u d i d a y a ~ P e r a i r a n, U n i v e r s i t a s ~ M a t a r a m, ~ M a t a r a m, ~ I n d o n e s i a ~}$ \\ ${ }^{2}$ Fakultas Ekonomi dan Bisnis, Universitas Mataram, Mataram, Indonesia \\ ${ }^{3}$ Fakultas Hukum Universitas Mataram, Mataram, Indonesia
}

DOI: https://doi.org/10.29303/jpmpi.v4i2.681

Sitasi: Lestari, D. P., Wijaya, M. R., Rachman, F. F., Wisasatra, A. H., \& Anharudin. (2021). Pemanfaatan Kulit Pisang Menjadi Produk Kopi Bubuk (KoKuPis). Jurnal Pengabdian Magister Pendidikan IPA, 4(2)

\author{
Article history \\ Received: 03 Februari 2021 \\ Revised: 08 Maret 2021 \\ Accepted: 10 April 2021 \\ *Corresponding Author: \\ Muamad Rachmat Wijaya, \\ Fakultas Ekonomi dan \\ Bisnis,Universitas Mataram, \\ Mataram, Indonesia; \\ Email: \\ rahmatbeko789@gmail.com
}

\begin{abstract}
Produk Kopi yang dihasilkan dalam kegiatan Kuliah Kerja Nyata (KKN) Universitas Mataram tema Penciptaan 1000 Wirausaha Baru (P1000WB) bertujuan untuk membantu perekonomian masyarakat Desa Karang Baru dan melatih mahasiswa dalam berwirausaha serta mengelolah limbah kulit pisang yang tidak termanfaatkan di lingkungan sekitar menjadi produk bernilai ekonomis. Kegiatan ini berlokasi di Desa Karang Baru Kecamatan Selaparang yang di laksanakan selama 45 hari. Metode pelaksanaan kegiatan ini cukup sederhana dengan cara mengumpulkan kemudian membersihkan kulit pisang, mengoven kulit pisang dengan suhu yang sudah di tentukan dan kemudian mencampurkannya dengan kopi bubuk khas lombok. Produk kopi yang dihasilkan ini cukup diminati hampir semua kalangan karena harganya yang terjangkau, rasanya yang nikmat, dan khususnya kopi ini mengandungan kaya antioksidan.
\end{abstract}

Keywords: Kopi; Kulit Pisang; Wirausaha.

\section{Pendahuluan}

Program KKN P1000WB merupakan salah satu tema Kuliah Kerja Nyata (KKN) yang dilaksanakan oleh Universitas Mataram dengan melibatkan mahasiswa dalam pelaksanaan KKN tersebut.Program ini untuk mendukung visi-misi pemerintah yang tertuang dalam Renstra Kemenristekdikti untuk pengembangan wirausaha baru dalam mewujudkan kemandirian bangsa melalui pengembangan pendidikan dan pelatihan kewirausahaan. Program KKN P1000WB diharapkan juga dapat menghasilkan karya kreatif, yang inovatif dalam membuka peluang bisnis yang berguna bagi mahasiswa setelah menyelesaikan studi (Tim Pelaksana, 2020).

Di Indonesia, pisang menduduki tempat pertama di antara jenis-jenis buah lainnya, baik dari segi sebaran, luas pertanaman maupun produksinya.
Produksi pisang di Indonesia pada tahun 2006 sekitar 5.037.472 ton (Mulyanti et al., 2008). Tanaman buah pisang terdiri dari akar, batang, daun, bunga dan buah. Buah pisang kerap dijadikan sumber vitamin dan mineral, selain sebagai buah yang dapat dikonsumsi secara langsung, pisang juga dapat juga digunakan sebagai olahan makanan seperti sale pisang, nagasari dan sebagainya. Bagian yang dapat dimakan dari buah pisang adalah dua pertiga bagian dan sepertiga bagian sisanya merupakan limbah pisang (Tety, 2006).

Salah satu produk yang bisa dikembangkan dari kulit pisang yaitu mengolahnya menjadi kopi. Kulit pisang mengandung karbohidrat, gula reduksi, gula non reduksi, protein, asam organic, lemak. Seluruh senyawa tersebut akan menjadi prekusor flavor dalam pembuatan kopi kulit pisang. Reaksi yang dimungkinkan terjadi pada suhu tinggi diatas $150{ }^{\circ} \mathrm{C}$ antara lain reaksi Maillard, karamelisasi, oksidasi dan pirolisi. Reaksi ini dapat 
menghasilkan senyawa antioksidan sehingga kopi yang dihasilkan akan mengandung senyawa antioksidan. Pembuatan kopi sangat dipengaruhi oleh lamanya interaksi bahan dengan suhu tinggi sehingga akan terjadi reaksi kimia yang membentuk cita rasa. Selain itu buah pisang yang dapat digunakan dari pisang mentah dan pisang matang (Mentari et al., 2019)

Dalam mendukung pelaksanaan kegiatan KKN P1000WB yang tujuannya untuk mengembangkan kreativitas mahasiswa yang memiliki minat wirausaha dan juga memberikan informasi kepada masyarakat melalui pemanfaatan limbah kulit pisang yang tidak termanfaatkan di daerah Desa Karang Baru, Kecamatan Selaparang. Oleh karena itu mahasiswa KKN membuat produk Kopi Bubuk yang memanfaatkan kulit pisang sebagai bahan utama dalam pembuatan produk kopi kulit pisang (KoKuPis) ini. Manfaat dari kegiatan ini diharapkan dapat membantu perekonomian masyarakat Desa Karang Baru dan melatih mahasiswa dalam berwirausaha serta mengelolah limbah di lingkungan sekitar menjadi produk yang bermanfaat dan bernilai ekonomis.

\section{Metode}

\section{Waktu dan Tempat Pelaksanaan}

Kegiatan ini berlokasi di Desa Karang Baru Kecamatan Selaparang yang di laksanakan selama 45 hari dari tanggal 11 Januari 2021 sampai dengan 25 Februari 2021, dengan jumlah anggota yang terlibat 4 orang terdiri dari ketua,divisi produksi,divisi design dan divisi marketing.

\section{Bahan dan Alat}

Bahan utama yang digunakan adalah kulit pisang kepok yang sudah matang. Bahan campuran yang digunakan adalah kopi bubuk hitam khas Lombok. Peralatan yang digunakan anatara lain yaitu baskom, blender kering, corong, kompor gas, wajan, nampan, oven, penyaringan, pisau, sendok, spatula, dan timbangan digital.

\section{Cara Pelaksanaan}

Adapun cara pelaksanaan pembuatan kopi bubuk kulit pisang yaitu menyiapkan alat dan bahan. Memilih, mencuci dan meniriskan kulit pisang. selanjutnya memotong kulit pisang menjadi ukuran yang lebih kecil untuk mempersingkat waktu pengeringan serta menata kulit pisang di atas nampan dan selanjutnya dijemur. Setelah kulit pisang agak kering maka angkat dan memasukannya ke dalam oven dengan suhu $150^{\circ} \mathrm{C}$ selama 75 menit. Setelah proses pengovenan selesai maka kulit pisang di blender dan diayak menggunakan saringan hingga memperoleh bubuk kulit pisang yang benar-benar halus. Kemudian mencampur bubuk kulit pisang dengan bubuk kopi khas Lombok hingga benar-benar tercampur dengan rata. Terakhir menimbang dan memasukan bubuk kopi kulit pisang kedalam kemasan dengan takaran 17 gr setiap bungkusnya.

\section{Hasil dan Pembahasan}

\section{Karakteristik Kopi Kulit Pisang}

Penampakan Produk Kulit Kopi kulit pisang yang dihasilkan dalam kegiatan ini tidak jauh berbeda dengan kopi pada umumnya hanya saja warnanya tidak terlalu hitam (Gambar 1). Aroma dari kopi kulit pisang tidak terlalu kuat (strong). Produk kopi kulit pisang memiliki keunggulan sendiri, antara lain: 1) memiliki cita rasa yang khas dan unik, 2) harga yang relative murah dan memiliki manfaat kesehatan bagi tubuh, dan 3) kemasan produk yang modern, sehingga dapat menarik perhatian konsumen.

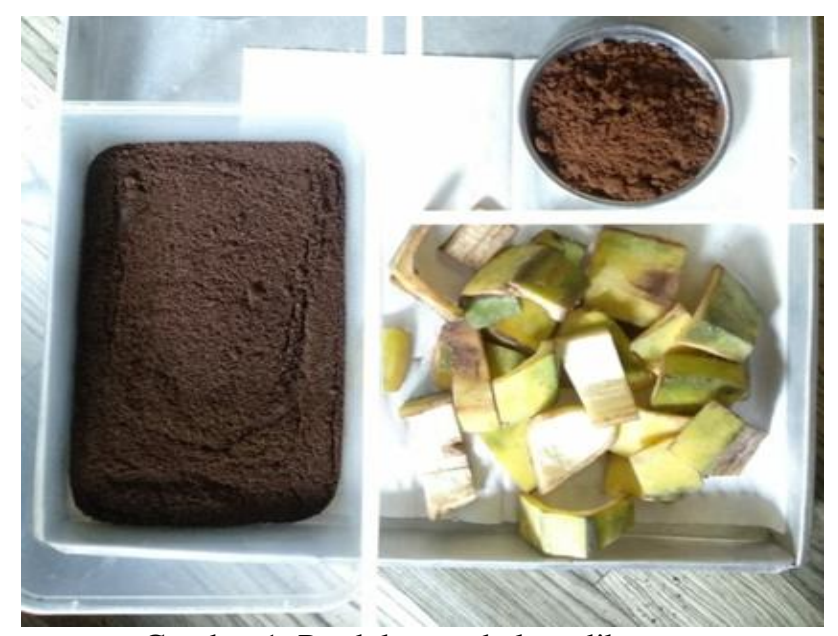

Gambar 1. Produk yang belum dikemas

Kandungan Fenol (antioksidan)

Kopi Kulit Pisang mengandung antioksidan yaitu senyawa fenol yang merupakan senyawa antioksidan yang banyak terdapat pada kopi. Kandungan fenol pada kopi kulit pisang mengalami perubahan yang signifikan. Kulit pisang secara 
umum memiliki kandungan total fenol sebesar 9,89-17,89 mg GAE/g. Tepung kulit pisang mengandung total fenol mencapai $29,2 \mathrm{mg} \mathrm{GAE} / \mathrm{g}$. Kandungan proantosianidin mencapai $3952 \mathrm{mg} / \mathrm{kg}$. Senyawa fenol dalam kulit pisang antara lain catecholamines, phenolic acid dan flavonoids (Rabello et al., 2014).

\section{Aktivitas Antioksidan}

Proses pembuatan kopi kulit pisang dalam kegiatan ini ada beberapa tahapan yang dilakukan salah satunya memilih kulit pisang yang matang (kulit sudah berwarna kuning) (Gambar 1). Dikarenakan kulit pisang matang memiliki aktivitas antioksidan yang lebih kuat dibandingkan kulit pisang mentah. Proses pengolahan Kulit Pisang menjadi kopi diduga mempengaruhi aktivitas antioksidan berupa psoses pengovenan dan penyangraian. Proses pengovenan dilakukan pada suhu tinggi diatas 150 'C dengan waktu selama 1 jam, dan proses penyangraian dilakukan pada suhu tinggi diatas 150 'C dengan waktu selama 15 menit. Proses pengovenan dan penyangraian ini melibatkan panas sehingga akan terjadi perubahan kimia yang membentuk flavor serta aroma. Reaksi yang terjadi pada suhu tinggi diatas 150 'C antara lain reaksi Maillard, karamelisasi, oksidasi, dan pirolisis.Reaksi millard ini diduga dapat meningkatkan aktivitas antioksidan yang disebabkan oleh pembentukan senyawa akrilamid.Pembentukan senyawa akrilamid antara asam amino dengan senyawa gula preduksi yang terjadi pada suhu tinggi.Asam amino yang menjadi prekursor akrilamid (bakal bahan pembentuk senyawa akrilamid) adalah aspagarin.Sedangkan karbohidrat yang menjadi prekusor akrilamid berupa gula preduksi (glukosa, fruktosa, dan maltosa) yang dapat ditemukan pada kulit pisang.Peningkatan aktivitas antioksidan dapat mengindikasikan bahwa terdapat peningkatan kandungan total fenol. Terdapat hubungan yang berbanding lurus antara kandungan total fenol dan aktivitas antioksidan (Supriyanti, 2015).

Aktivitas antioksidan menunjukkan kemampuan senyawa antioksidan dalam scavenging radikal DPPH.Senyawa antioksidan yang ada dalam kopi kulit adalah fenol.Kemampuan scavenging radikal DPPH ini dihitung pada beberapa konsentrasi ekstrak sehingga diperoleh nilai konsentrasi penghambatan $50 \%$ (IC50). Semakin kecil nilai IC50 menunjukkan aktivitas antioksidan suatu senyawa semakin kuat.Semakin lama pengovenan menyebabkan nilai IC50 semakin menurun yang menandakan aktivitas antioksidannya semakin kuat.Tingkat kematangan yang semakin meningkat menyebabkan penurunan nilai IC50 secara signifikan.Hal ini menandakan kopi kulit pisang matang memiliki aktivitas antioksidan yang lebih kuat dibandingkan kopi kulit pisang mentah.Pola nilai IC50 ini bersesuaian dengan pola nilai fenol.Semakin meningkat kandungan fenol makan nilai IC50 semakin turun.Penelitian pada kopi dengan semakin meningkatnya lama penyangraian menyebabkan aktivitas antioksidannya semakin meningkat dan nilai IC50 semakin menurun dan diiringi peningkatan senyawa fenol (Ludwig et al., 2013). Nilai IC50 kopi kulit pisang lebih tinggi dari kulit pisang segar. Nilai IC50 kulit pisang berkisar 55,45-120,03 $\mu \mathrm{g} / \mathrm{ml}$ (Mentari et al., 2019).
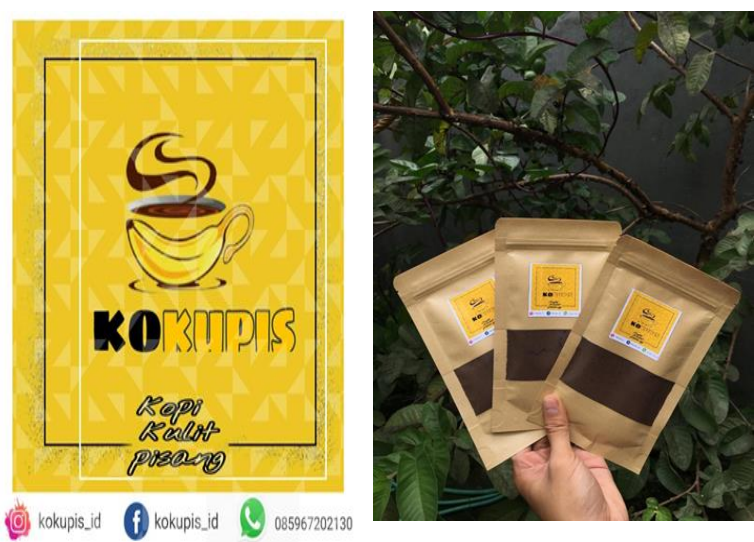

Gambar 2. Label dan Kemasan dari Kopi kulit pisang

\section{Pangsa Pasar}

Target Pasar dari produk ini adalah semua kalangan masyarakat khususnya remaja, bapak bapak dan ibu rumah tangga yang berada di lingkungan Desa karang baru dan masyarakat di luar Desa karang baru. Karena tingkat kebutuhan masyarakat akan kopi sanagat tinggi.Untuk merealisasikan target, kami melakukan strategi pemasaran melalui media online seperti Whatsapp dan Instagram. Kami juga menawarkan produk kami ke semua warung dan kedai yang berada di lingkungan Desa Karang Baru, "Kopi Kulit Pisang yang dihasilkan memiliki nilai kesukaan konsumen yang baik. Hasilnya memuaskan, karena konsumen menyukai rasa kopi yang berpadu dengan aroma 
pisang yang menjadi ciri khas tersendiri dan harga yang terjangkau relatif murah, "Kita berharap ke depan, kopi kulit pisang ini bisa diterima masyarakat luas, sekaligus menjadi alternatif bubuk kopi konvensional yang selama ini sudah ada.

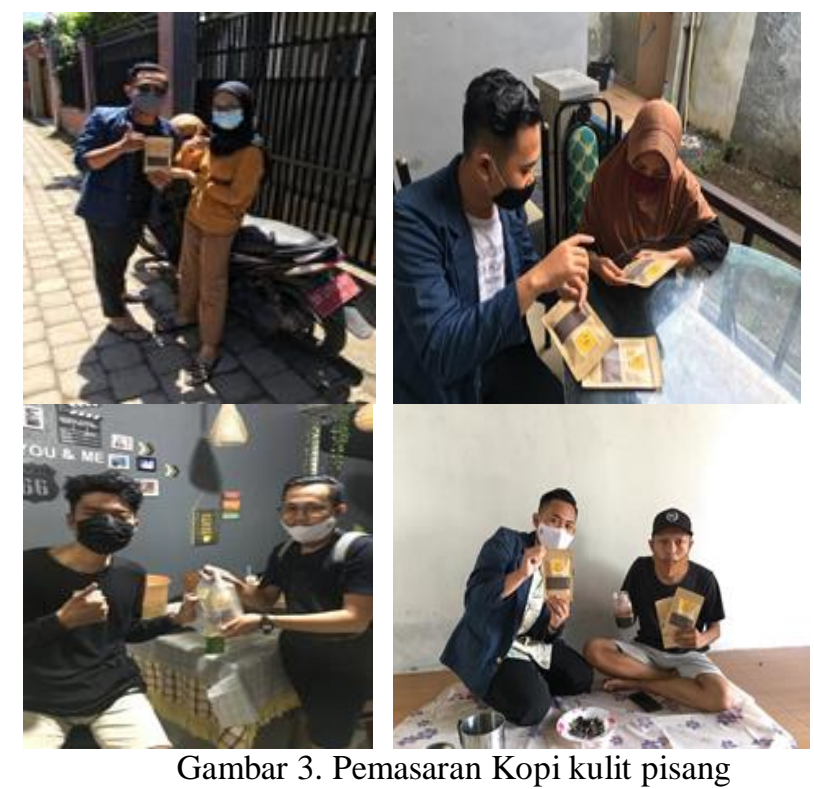

\section{Kesimpulan}

Dari tujuan, hasil, dan juga pembahasan, maka dapat disimpulkan bahwa telah terciptanya usaha baru di Desa Karang Baru dengan memanfaatkan limbah kulit pisang menjadi produk bernilai ekonimis yaitu kopi kulit pisang kaya antioksidan dan cukup diminati oleh kalangan remaja, bapak-bapak bahkan ibu rumah tangga karena harga terjangkau, rasanya nikmat serta memiliki banyak manfaat kesehatan untuk tubuh.

\section{Saran}

Sebaiknya pada saat pengovenan kulit pisang lebih diperhatiakn suhu dan juga waktu agar manfaat dan citra rasa dari produk tetap terjaga. Serta teknik penjualan dan variant rasa lebih diperbanyak sehingga dapat lebih menarik minat masyarakat.

\section{Daftar Pustaka}

Mentari, A.B., dkk. Pembuatan Kopi dari Kulit Pisang Kepok (Musa paradisiaca Linn) dan Aktivitas Antioksidannya. Jurnal Ilmu
Pangan dan Hasil Pertanian. 3 (1) hal: 95.

Mulyanti, N., Suorapto, dan Jekvy H. 2008. Teknologi Budidaya Pisang. Bogor: Agro Inovasi.

Rebello,dkk. 2014. Flour of banana (Musa AAA) peel as a source of antioxidant phenolic compounds. Food Research International.hal:397-403.

Supriyanti, F.M.T. Suanda, H. Dan Rosdiana, R. 2015. Pemanfaatan Ekstrak Kulit Pisang Kepok (Musa Bluggoe) Sebagai Sumber Antioksidan Pada Produksi Tahu.Seminar Nasional Kimia VII. Universitas Sebelas Maret Surakarta, pp 393-400

Tety. 2006. Kandungan Kulit Pisang.URL: www.risvank.com/reaksibioetanol. Diakses pada tanggal 3 Maret 2021.

Tim Pelaksana., 2020. Panduan Kuliah Kerja Nyata (KKN) Era New Normal Universitas Mataram, Lembaga Penelitian dan Pengabdian Universitas Mataram Mataram. Hal 5. 